for short) that has such a precisely descriptive and stable system of nomenclature as chemistry.

The chemist, if diligent, can make at least one new compound every day or so and in his spare moments give it a name. Often it is easier than deciding what to call a new baby. The name he gives will generally stick, because only on rare oceasions does some other chemist come along and show that the harness got twisted when the radicals were hitched up. Then all that is needed is to rearrange the component parts of the name or to substitute "ortho" for "para" or "meta."

The name tells what the substance is. Doubt arises when a short and easy name is applied. For the chemist a good name is rather to be chosen than great wealth of description, because it in If-rmutainet. The naturalist must have itrailed descriptions, preferably with plates, and is happiest when he can make comparison with "type specimens."

In his spare moments the botanist or zoologist digs around in old books and journals with the hope of resurrecting an old name for some familiar plant or animal. This is called stabilizing the nomenclature. It is done because such and such a congress decided that the race for supremaey and final adoption shall be won, not by a name that has come swiftly down the years and is known by all, but by one that stayed at scratch, hidden in some dusty volume.

Shuffling the cards for a new deal is another delightful diversion. For such names as $\mathrm{X}$........ a....... (Smith) Jones comb. nov. special honors are awarded, particularly to Jones. The pity of it is that somebody else may come along and soon the specimen becomes Y....... b........ (Brown) White comb. noviss. In this way the nomenclature becomes fixed.

What is queer about a chemical spelling match? To name a compound for which the formula is given, or to do the reverse, is good training for the memory. Can one imagine a botanical or an entomological spelling match? Could "aster" or "grasshopper" be drawn in recognizable detail by the contestants? The optimistic chemist will concede that the respective drawings could with some confidence be labelled "flower" or "bug," but could an expert name the species? Yet the pitifully un- scientific chemist who uses long words to eloak his ignorance ean at once tell the correct names of two such closely related species as $\mathrm{H}_{2} \mathrm{SO}_{3}$ and $\mathrm{H}_{2} \mathrm{SO}_{4}$.

$$
\begin{aligned}
& \text { WASHINGTON, D. C. } \quad \text { C. E. WATERS } \\
& \text { OCTOBER } 27,1922
\end{aligned}
$$

\section{MUSCINA PASCUORUM MEIGEN IN NEW ENGLAND}

THIS European fly has made its appearance in considerable numbers this year in Massachusetts and Connecticut. The first specimen was collected in Connecticut, August 6, and it is still (November 14) quite common in the vicinity of Boston. The muscid is about three times the size of the house fly, bluish black, with a whitish, pruinose covering. A detailed account is in preparation and any information as to its further distribution will be greatly appreciated.

Boston Society of Natural History

\section{SCIENTIFIC BOOKS}

The Minds and Manners of Wild Animals. By

Wrlliam T. Hornaday, Sc.D., A.M. New

York: Charles Scribner's Sons, 1922. Pp. $\mathrm{x}+328$.

If every man devoted to his affairs, and to the affairs of his city and state, the same measure of intelligence and honest industry that every warmblooded wild animal devotes to its affairs, the people of this world would abound in good health, prosperity, peace and happiness.

To assume that every wild beast and bird is a sacred creature, peacefully dwelling in an earthly paradise, is a mistake. They have their wisdom and their folly, their joys and their sorrows, their trials and tribulations.

As the alleged lord of creation, it is man's duty to know the wild animals truly as they are, in order to enjoy them to the utmost, to utilize them sensibly and fairly, and to give them a square deal.

With these reflections, the dean of scientific directors of American zoological parks presents his volume on the minds and manners of wild animals. And with the following picture -reproduced here only in part-the curtain falls:

On one side of the heights above the River of 